\title{
WestVirginiaUniversity
}

THE RESEARCH REPOSITORY @ WVU

West Virginia Agricultural and Forestry Experiment

Davis College of Agriculture, Natural Resources

Station Bulletins

And Design

$1-1-1927$

\section{A Study of the Hardiness of the Fruit Buds of the Peach}

\author{
H. E. Knowlton
}

Maxwell J. Dorsey

Follow this and additional works at: https://researchrepository.wvu.edu/ wv_agricultural_and_forestry_experiment_station_bulletins

\section{Digital Commons Citation}

Knowlton, H. E. and Dorsey, Maxwell J., "A Study of the Hardiness of the Fruit Buds of the Peach" (1927). West Virginia Agricultural and Forestry Experiment Station Bulletins. 211.

https://researchrepository.wvu.edu/wv_agricultural_and_forestry_experiment_station_bulletins/211 @ WVU. It has been accepted for inclusion in West Virginia Agricultural and Forestry Experiment Station Bulletins by an authorized administrator of The Research Repository@WVU. For more information, please contact ian.harmon@mail.wvu.edu. 
EMASDALE LIBRARY
WEST VBGINIA

URMERSITY 


\section{Restricted}

\section{Circulation Only}

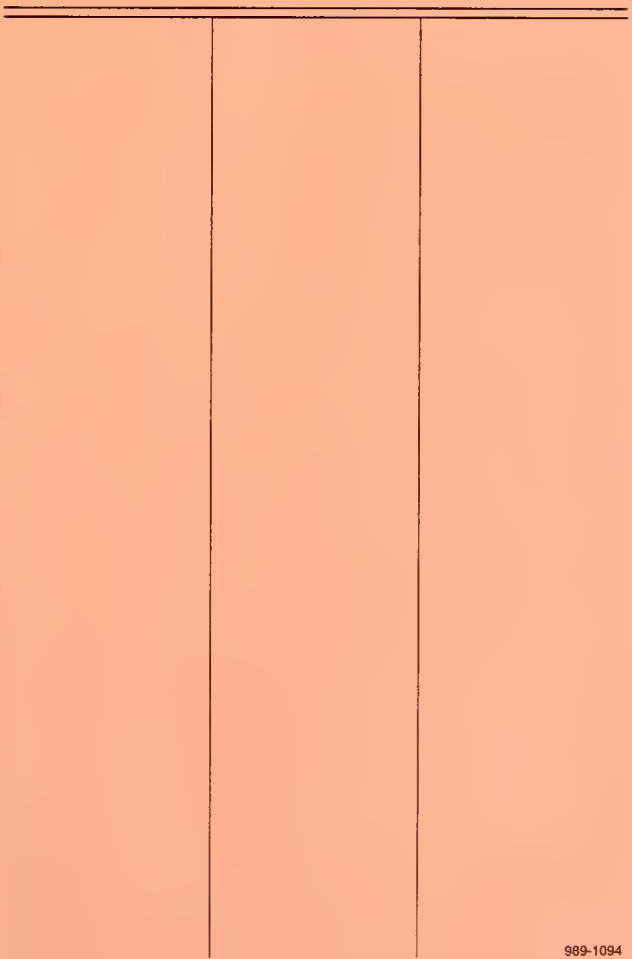





\section{Ayritultural firperiment Station}

College of Agriculture, West Virginia University

N. J. Giddings, Acting Director

Morgantown

\section{A Study of the Hardiness of the Fruit Buds of the Peach}

[TECHNICAL]

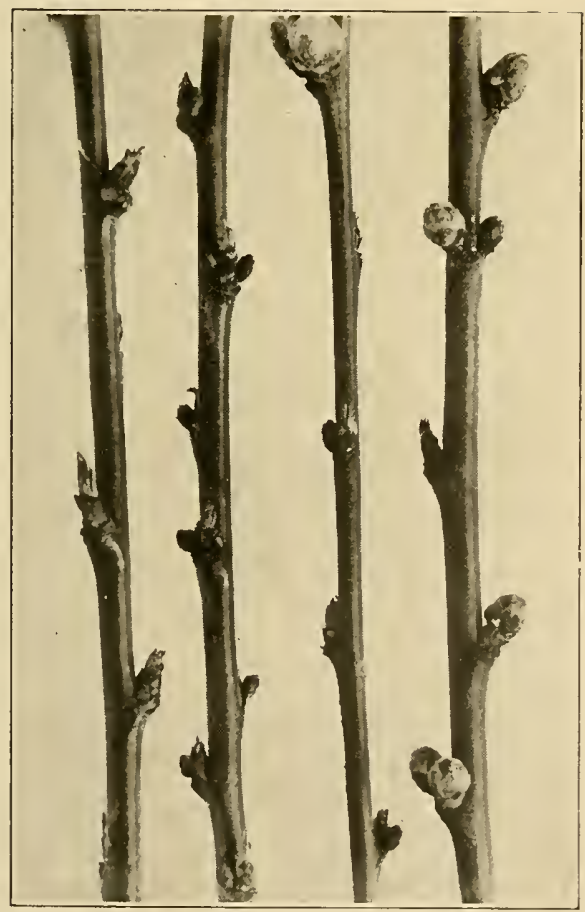

By

H. E. KNOWLTON and M. J. DORSEY 


\section{AGRICULTURAL EXPERIMENT STATION STAFF}

FRANK BUTLER TROTTER, A. M., LL. D.

President of the Univers

N. J. GIDDINGS, Ph. D.

Acting Dean and Direc

WALTER C. SCHNOPP, B. S. Agr.

Agricultural Edis

JOHN C. JOHNSTON.

\section{AGRONOMY AND GENETICS}

R. J. Garber, Ph. D.

Agronomist and Geneticist

E. P. Deatrick, Ph. D.

Associate Agronomist (Soils)

T. E. Odland, Ph. D.

Associate Agronomist

T. C. Mellvaine, Ph. D. $\dot{\dagger}$

Assistant Agronomist (Soils)

D. R. Dodd, M. S.

Assistant Agronomist

M. M. Hoover, M. S.

Junior Agronomist

H. K. Rowley, M. S. Agr.** Seed Analyst

\section{ANIMAL HUSBANDRY}

E. A. Livesay, M. S.

Animal Husbandman

Chas. V. Wilson, M. S.

Assistant Animal Husbandman

J. H. Longwell, M. A.

Assistant Animal Husbandman

J. H. Rietz, D. V. M.

Associate Veterinarian

R. H. Tuckwiller, B. S. Agr.*

Assistant Animal Husbandman

\section{CHEMISTRY}

R. B. Dustman, Ph. D.

Associate Chemist

Chas. E. Weakley, Jr., B. A.

Ässistant Chemist

L. P. Hansen, Ph. D.

T. B. Leith, B. A.**

Assistant Chemist

Assistant Chemist

Leland Shriver

Assistant in Chemistry

\section{DAIRY HUSBANDRY}

E. L. Anthony, M. S. Agr.

Dairy Husbandman

H. O. Henderson, M. S. Agr.

Associate Dairy Husbandman

G. Malcolm Trout, M. S.

Assistant Dairy Husbandman

\section{ENTOMOLOGY}

L. M. Peairs, Ph. D.

W. E. Rumsey, B. S.**

L. E. Dills, M. S.**

State Entomologist

Assistant in Entomology
FARM ECONOMICS

A. J. Dadisman, Ph. D.

Farm Econon

Paul A. Ekke, Ph. D.

Assistant Farm Econom

F. D. Cornell, Jr., M. S.

Junior Farm Mechanic

W. W. Armentrout, M. S.

Junior Farm Econom

HOME ECONOMICS

Rachel H. Colwell, A. M.

Hazel C. Cameron, M. S.

Home Econon

Research Specialist in Fo

Nell Nesbitt, A. M.

Research Specialist in Home $\mathrm{V}$

\section{HORTICULTURE}

H. E. Knowlton, Ph. D.

Associate Horticultu

H. L. Crane, M. S. Agr.

Associate Horticultu

K. C. Westover, M. S. Agr.

Assistant Horticultu

Ernest Angelo, M. S. Agr.

Junior Horticultu

L. F. Sutton, B. S. Agr.

Assistant Horticultu

H. P. Sevy, M. S. Agr.

Assistant in Horticult

M. B. Hoffman, M. S.

Assistant in Horticult

\section{PLANT PATHOLOGY}

N. J. Giddings, Ph. D.

Anthony Berg, M. S.

Plant Patholos Associate Plant Patholos

L. H. Leonian, Ph. D. Associate Plant Patholos

E. C. Sherwood, M. S.

Assistant Plant Patholo

\section{POULTRY HUSBANDRY}

Horace Atwood, M. S. Agr.

Poultry Husbandm

E. T. Wightman, M. S. Agr.

Junior Poultry Husbandn

RURAL SOCIOLOGY

T. L. Harris, Ph. D.

Rural Sociolos

\section{ZOOLOGY}

F. E. Chidester, Ph. D.

Zoolo

*In cooperation with the U. S. Department of Agriculture, Washington, D. C. In charge of the Lakin Sub-station, Lakin, W. Va.

**In cooperation with the State Department of Agriculture, Charleston, W. Va.

†In charge of the Reymann Memorial Farms, Wardensville, W. Va. 


\section{A Study of the Hardiness of the Fruit Buds of the Peach*}

Winter lilling of the fruit buds of the peach in West Virginia is serious limiting factor to an otherwise profitable crop. In some etions a crop failure from this cause alone may occur as often as two even three times in a five-year period. This problem has been given nsiderable study in the peach-growing regions of other states, and $y$ be considered as separate and distinct from that of the injury to wers and young fruits by spring frosts. In this investigation, in est Virginia, attention has been given to the following points: (a) the lative hardiness of the fruit buds of some of the more important rieties, (b) the stages of development in the fruit bud throughout e season, and (c) the influence of culture and fertilizers upon fruitd hardiness. These three phases of the subject will be taken up in order named.

The wood of the varieties under observation in this study was und to be injured less frequently than the fruit buds. During the nter of 1924-25 some wood injury oceurred, but as far as observains were made, only young or rapidly growing trees were affected. hen winter conditions in this state kill all the fruit buds, there may so be some killing of the wood. It rarely happens in this latitude at the fruit buds prove to be hardier than the wood, although an stance of this condition was reported in Ohio by Thayer (1916). The it buds, therefore, may be regarded as a more sensitive index to rdiness than the wood.

\section{ME EFFECTS OF WINTER CONDITIONS IN WEST VIRGINIA}

The problem of fruit-bud hardiness with the peach, Japanese plum, d sweet cherry is apparently more important in the latitude of West rginia than it is farther north. This is because of the mild winters th frequent periods of warm weather. Figure 1 shows daily maxiim and minimum temperatures for the winter of 1921-1922. It will seen in this figure that maximum temperatures were above $50^{\circ} \mathrm{F}$. ht times and above $60^{\circ}$ three times during Deeember, January, and bruary. On February 25 the temperature was $75^{\circ} \mathrm{F}$. These warm 


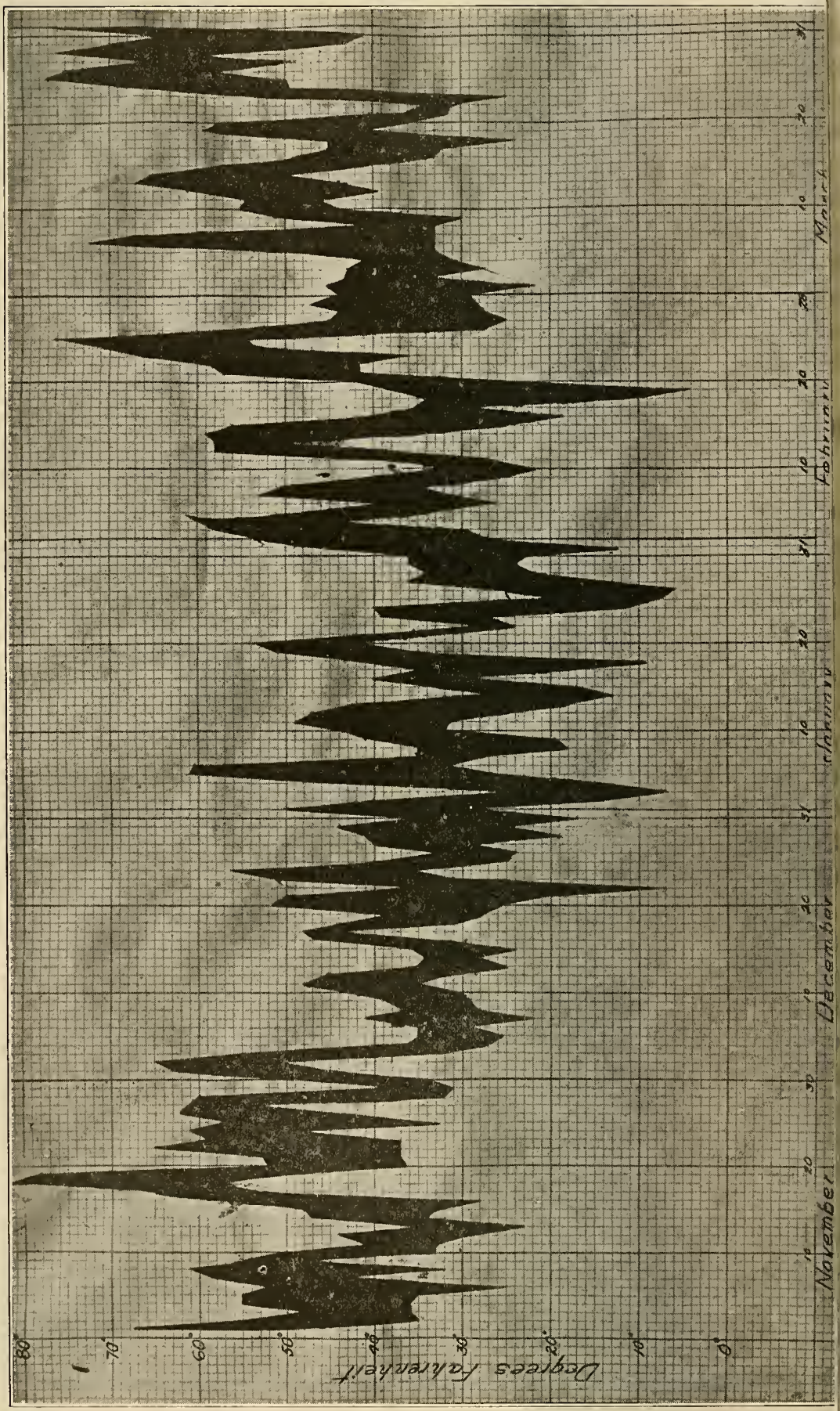


bells, if they oecur toward the end of the rest perind in early . Jamury hd later, start buds into growth. This brings about a marked de-ease in their resistance to subsequent low temperatures. In the inter of 1924-1925 almost all fruit buds on the tender and semi-hardy urictics of peach in the Experiment Station Orchard were killed by a udden drop in temperature to $-9^{\circ} \mathrm{F}$., following a periocl of warm Neather in late January. In the northern peach sections of New Tork, ichigan, and Ontario, where warm periods seldom occur during inter, peach buds have withstood temperatures as low as $-20^{\circ} \mathrm{F}$. ithout injury. This extreme resistance, however, is only shown at e end of long eold periods.

\section{ARIETAL DIFFERENCES IN THE HARDINESS OF FRUIT BUDS}

It is generally recognized by peach growers that the fruit buds of me varieties are hardier than those of others. This condition has en given some study in West Virginia, and in this latitude significant fferences were found when a survey was made of some of the more portant varieties.

In the spring of 1923 the condition of all of the fruit buds on two ndred nodes, each of some of the more important commercial ricties under test in the Experiment Station variety orchard, was idied. This classification was made at the pink stage, but before the nter-killed fruit buds had fallen. At this time the winter-killed iit buds could easily be distinguished from those not killed, by ferences in size. A study of Table 1 will show interesting differences the effect of winter temperatures on the different varieties.

While there was considerable killing in all of the rarieties', some them like Reeves, Nectar, and Bilmeyer Jost nearly all of their fruit ds from winter killing. The contrast between these and Belle, rton, Greensboro, or Hiley, in the number of fruit buds or flowers viving the winter, is noticeable. An interesting feature of the ling in this season was the large number of dead pistils in some rieties. This conditon appeared to be peculiar to this season, in w of the fact that only an occasional dead pistil could be found the lowing season.

Death was apparently due to occurrence of low temperature after isiderable growth had taken place. This indicates that the pistil more susceptible to injury at certain stages of growth than are the er parts of the flower. When only the pistil is killed, bloom oceurs ian apparently normal manner, but the flowers drop a few days after ning. Pistil injury was especially noticeable in Carman and Late 
TABLE 1.-Fruit Bud Condition on Selected Commercial Varieties of Pea Following the Winter of 1922-1923.

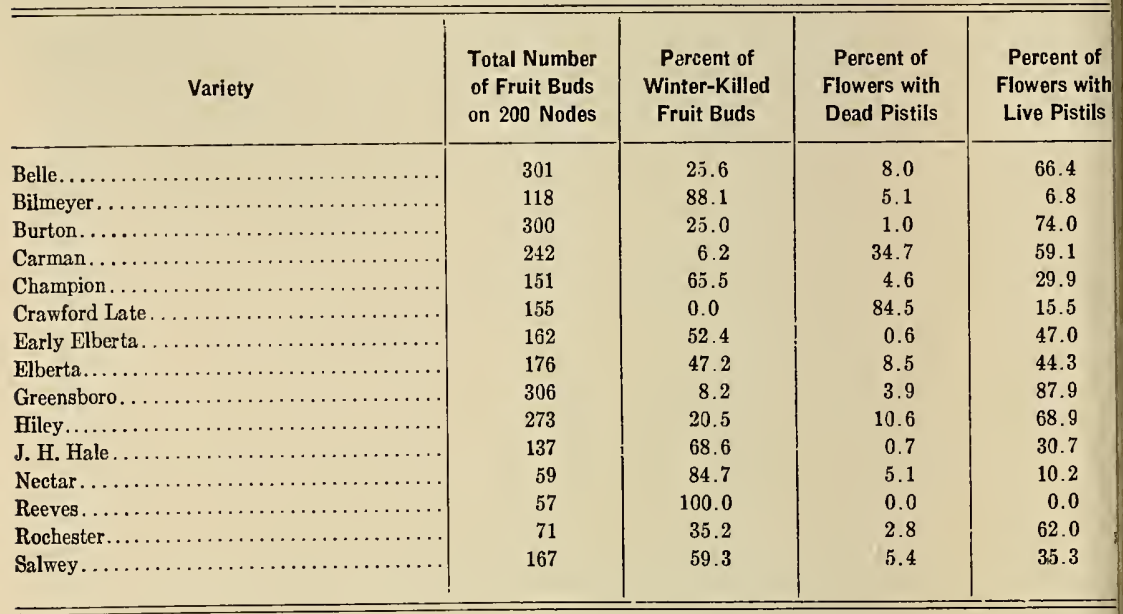

Crawford. It will be seen, then, that at bloom, all the fruit buds pr duced in the fall can be grouped into three categories as listed Table 1. It is evident that the crop must be obtained from the flowe: with live pistils. A similar classification in other years may show marked difference in the grouping of the buds under the differes headings of this table.

The study of the relative hardiness of fruit buds on the termin growths and on the shorter lateral growths on the interior of the tr discloses some interesting differences. The data on this point as summarized in Table 2.

As before, the buds on 200 nodes were made the basis of cor parison. Fruit-bud production was relatively heavy the year th: these counts were made, and marked differences were found betwee varieties. The varieties also varied considerably in the percentages fruit buds killed. In Belle and Crawford, there was slightly le killing of buds' on the inner lateral growths than of those on the out terminal growths. Elberta, on the other hand, showed considerab. more killing on the short lateral growths on the inner part of the tre Rochester was in the same category, but not so pronounced. It possible that, if larger numbers of fruit buds of these varieties ha been counted, different results would have been obtained.

In making these counts of killed buds, attention was not given the relative hardiness of buds borne on the basal, median, and termin parts of the longer outer growths. Observations, however, during tl 
ABLE 2.-The Relative Hardiness of Fruit Buds Borne on Short and Long Growths During the Season of 1923-1924.

\begin{tabular}{|c|c|c|c|c|c|c|c|c|c|}
\hline \multirow[b]{2}{*}{ Variety } & \multirow[b]{2}{*}{ Trees } & \multicolumn{3}{|c|}{$\begin{array}{l}\text { Spurs or Laterals Less } \\
\text { Than } 31 / 2 \text { Inches } \\
\text { in Lenjth }\end{array}$} & \multicolumn{3}{|c|}{$\begin{array}{l}\text { Outside Terminal } \\
\text { Growths } 16 \text { to } 20 \\
\text { Inches Long }\end{array}$} & \multirow[b]{2}{*}{\begin{tabular}{|} 
Percent \\
Fruit Buds \\
Killed \\
on \\
Short \\
Growths
\end{tabular}} & \multirow[b]{2}{*}{$\begin{array}{c}\text { Percent } \\
\text { Fruit Buds } \\
\text { Killed } \\
\text { on } \\
\text { Terminals }\end{array}$} \\
\hline & & $\begin{array}{l}\text { Number } \\
\text { of } \\
\text { Nodes }\end{array}$ & $\begin{array}{l}\begin{array}{c}\text { Number } \\
\text { of } \\
\text { Flowers } \\
\text { Alive }\end{array}\end{array}$ & $\begin{array}{c}\text { Number } \\
\text { of } \\
\text { Fruit Buds } \\
\text { Winter- } \\
\text { Killed }\end{array}$ & $\begin{array}{l}\text { Number } \\
\text { of } \\
\text { Nodes }\end{array}$ & $\begin{array}{l}\text { Number } \\
\text { of } \\
\text { Flowers } \\
\text { Alive }\end{array}$ & $\begin{array}{c}\begin{array}{c}\text { Number } \\
\text { of } \\
\text { Fruit Buds } \\
\text { Winter- } \\
\text { Killed }\end{array}\end{array}$ & & \\
\hline He & $\begin{array}{l}1 \\
2 \\
3 \\
4\end{array}$ & $\begin{array}{l}200 \\
200 \\
200 \\
200\end{array}$ & $\begin{array}{r}107 \\
99 \\
168 \\
126\end{array}$ & $\begin{array}{r}51 \\
70 \\
99 \\
102\end{array}$ & $\begin{array}{l}200 \\
200 \\
200 \\
200\end{array}$ & $\begin{array}{l}65 \\
69 \\
93 \\
95\end{array}$ & $\begin{array}{r}106 \\
110 \\
122 \\
73\end{array}$ & $\begin{array}{l}32 \\
41 \\
37 \\
45\end{array}$ & $\begin{array}{l}62 \\
61 \\
57 \\
43\end{array}$ \\
\hline $\begin{array}{l}\text { te } \\
\text { Crawford }\end{array}$ & $\begin{array}{l}1 \\
2 \\
3 \\
4\end{array}$ & $\begin{array}{l}100 \\
200 \\
200 \\
200\end{array}$ & $\begin{array}{l}24 \\
21 \\
20 \\
29\end{array}$ & $\begin{array}{r}81 \\
163 \\
184 \\
181\end{array}$ & $\begin{array}{l}200 \\
200 \\
200 \\
200\end{array}$ & $\begin{array}{r}14 \\
8 \\
8 \\
19\end{array}$ & $\begin{array}{l}128 \\
166 \\
125 \\
139\end{array}$ & $\begin{array}{l}77 \\
89 \\
90 \\
86\end{array}$ & $\begin{array}{l}90 \\
95 \\
94 \\
88\end{array}$ \\
\hline jerta & $\begin{array}{l}1 \\
2 \\
3\end{array}$ & $\begin{array}{l}200 \\
200 \\
200\end{array}$ & $\begin{array}{l}37 \\
44 \\
35\end{array}$ & $\begin{array}{l}142 \\
146 \\
141\end{array}$ & $\begin{array}{l}200 \\
200 \\
200\end{array}$ & $\begin{array}{l}44 \\
16 \\
17\end{array}$ & $\begin{array}{l}31 \\
19 \\
20\end{array}$ & $\begin{array}{l}79 \\
77 \\
80\end{array}$ & $\begin{array}{l}41 \\
54 \\
54\end{array}$ \\
\hline Rochester & $\begin{array}{l}1 \\
2 \\
3 \\
4\end{array}$ & $\begin{array}{l}200 \\
200 \\
200 \\
200\end{array}$ & $\begin{array}{l}127 \\
110 \\
106 \\
109\end{array}$ & $\begin{array}{r}73 \\
114 \\
97 \\
43\end{array}$ & $\begin{array}{l}200 \\
200 \\
200 \\
200\end{array}$ & $\begin{array}{r}91 \\
118 \\
92 \\
98\end{array}$ & $\begin{array}{l}50 \\
59 \\
51 \\
55\end{array}$ & $\begin{array}{l}37 \\
51 \\
43 \\
28\end{array}$ & $\begin{array}{l}35 \\
33 \\
36 \\
36\end{array}$ \\
\hline
\end{tabular}

inter of 1924-25 showed that the few buds still alive were either on spurs'" or on the base of terminals. Chandler (1908) found that me of the hardiest buds on the tree were borne at the base of the rminal growths. It will be shown later that the buds in this posion lag behind the others in development during winter and come ito bloom more slowly in the spring.

In the studies of the relative hardiness of some of the more imortant varieties in the eastern and western parts of the state, the ata in Table 3 were obtained. The records cover three years at corgantown, two at Mason City and at Metz, but only one year at te other locations. Sixteen varieties in all are included in the table. ruit buds were counted on from 200 to 700 nodes.

The percentages of the fruit buds killed each year at Morgantown ad at Metz were relatively large, although one-fourth of the fruit ads, or even fewer, would be ample for a full crop if all were to set uit. When the percentage of fruit buds killed at Morgantown and Metz during 1923-24 is compared by varieties with the fruit-bud lling at points east of the mountains, it is evident that there is much 


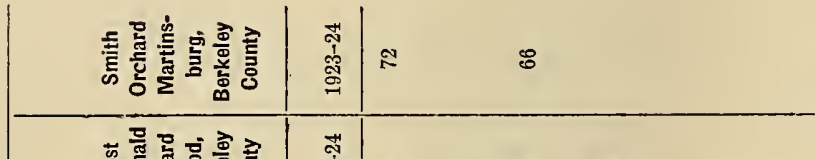

\begin{tabular}{|c|c|c|c|c|c|}
\hline 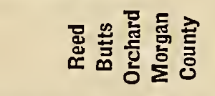 & 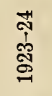 & 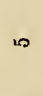 & $\infty 0$ & 잉 & 운 \\
\hline 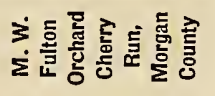 & $\begin{array}{l}\text { ज゙ } \\
\text { สิ } \\
\text { 今్ }\end{array}$ & 0 & $H$ & 0 & 90 \\
\hline
\end{tabular}

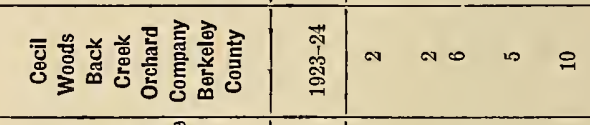

\begin{tabular}{|c|c|c|c|c|}
\hline 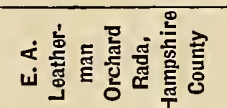 & $\begin{array}{l}0 \\
1 \\
30 \\
09 \\
0\end{array}$ & 유 으용 & ஃ ৪ $ஃ 88: 8$ & $8 \%$ \\
\hline
\end{tabular}

突

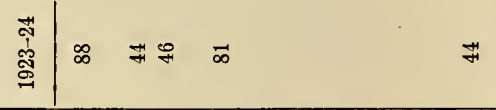

\begin{tabular}{|c|c|}
\hline 変 & 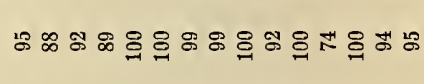 \\
\hline
\end{tabular}
蓲 言

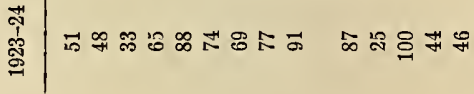

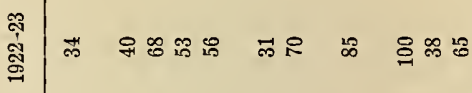

\begin{tabular}{|c|c|c|c|c|c|c|}
\hline \multirow{2}{*}{ 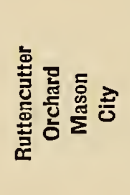 } & 永 & ชี & 串 & 1828 & 18 & $\vec{A}:$ \\
\hline & $\begin{array}{l}\text { ते } \\
\text { ळ } \\
\text { ఏ }\end{array}$ & & $\infty$ & i⿱ & त् & \&ి \\
\hline
\end{tabular}


ess injury in the eastern comnties. This is probably due to the more miform temperatures that prevail there.

The records of Belle and Elberta in the Smith orchard near Marinsburg may appear exceptional, but the bud killing in this instance vas determined from young trees which had grown until relatively ate the previous season. There was but little difference between the ercent of the fruit-bud killing in the Butts orchard, with young trees, nd in the Woods and Fulton orchards, with older trees." The trees in he Experiment Station and Metz orchards were about seven years ld in 1925.

It is interesting to note the bud killing each year in Reeves as ompared with some of the other varietics. Blake and Connors (1918) ound that varieties like Reeves, Early Crawford, Late Crawford, and Iountain Rose are much more susceptible to fruit-bud injury than reensboro, Carman, and Belle. Elberta and J. H. Hale have also een injured extensively in the West Virginia Experiment Station rchard. There was a complete loss in a number of varieties in the ime orchard in the winter of 1924-25. During the same winter, in the istern part of the state, the killing of fruit buds appeared to be somehat variable, some orchards coming through the winter with relavely light injury, while others near by were severely injured. Spring osts, however, soon after bloom, killed practically all the flowers maining after the winter killing.

The greater hardiness of the fruit buds of some varieties may have msiderable significance when measured by yield. Chandler (1908) ys that if only three to ten percent of the fruit buds were to set, ere would be enough to produce a full erop of fruit. In 1906 he und that peach trees, with 90 percent of their fruit buds killed, set good crop of fruit. Blake and Farley (1911) observed that experiteed fruit growers are generally satisfied if one-half of the fruit buds rvive the winter and early spring. It is evident, however, that with Iy a small percentage of the fruit buds surviving the winter or early ring low temperatures, a crop will depend very largely upon favorle weather conditions at pollination time.

In stressing the influence of regularity of bearing upon profitable ach growing, Odell (1924) writes regarding a test of twenty-five rieties, in which five to twenty trees of each were planted: "Planted 1916, these trees bore a fair crop in 1919, and heavy crops in 1920 , 22, and 1924. Such hardy varieties as Carman, Greensboro, and layflower bore well in 1923, also doubled the production of other rieties in 1919, making five erops against three and one-half for 
most of the others." Differences in the relative hardiness of the frui buds may, therefore, have a far-reaching influence upon fruit produc tion. Unfortunately, however, when consideration is given to th selection of varieties on the basis of the hardiness of the winter bud other factors must be taken into consideration. The outstanding fac of the peach situation is the dominance of Elberta, which is one of th tenderest varieties as measured by fruit-bud killing. Local condition and market preference must determine whether it is safe to conside substituting other varieties, wholly or in part, for Elberta.

\section{GROWTH AND DEVELOPIMENT OF FRUIT BUDS DURING DORIMANT SEASON}

All of our deciduous fruit trees normally have an annual perioc when their tops do not grow perceptibly even if environmental con ditions are favorable. This is commonly called the "rest period." I comes on gradually soon after terminal buds are formed in late summer or early fall and continues until some time in winter, the length of the period depending on the kind of fruit. During December in the case of the peach, the rest becomes less profound, and the frui buds start growing if weather conditions are favorable. This gradua breaking of the rest period of Elberta, Rochester, and Belle for the season of 1921-22 is clearly shown in Table 4.

Branches from three trees of each variety were taken to the greenhouse on the dates stated in the table and placed in water. The time elapsing before blossoms opened on these branches was used as an index of the condition of rest. All the varieties were coming out of the rest period by January 3 , and as the season advanced al] responded more rapidly to the favorable conditions of the greenhouse No branches were taken to the greenhouse in the period between December 1 and January 3, consequently, the bloom tests do not show just when the break occurred. In the winter of 1922-23, branches brought in on December 12, bloomed January 9. Hodgson (1924) found that the rest period of the peach ended in California by January 9 tc January 26. In Missouri, according to Howard (1910), the peach grew readily as early as January 8 . Johnson (1923) reported similar results in Maryland.

Table 4 also shows that Elberta seemed to have a slightly shorter rest period than either Rochester or Belle. This corroborates the observations of Blake (1916), who says that in the winter of 1915-16 there was a good set of fruit buds in one orchard, and that during January "a period of extremely warm weather started the buds to 
TABLE 4.-The Break in the Rest Period as Indicated by Date of Bloom of Cut Branches Kept in Water in Greenhouse (1921-1922).

\begin{tabular}{|c|c|c|c|c|}
\hline Varieties & $\begin{array}{l}\text { Dates Cut } \\
\text { Branches } \\
\text { Were Taken } \\
\text { to Greenhouse }\end{array}$ & $\begin{array}{l}\text { Dates } \\
\text { of } \\
\text { Bloom }\end{array}$ & $\begin{array}{l}\text { Number } \\
\text { Days } \\
\text { Before } \\
\text { Bloom }\end{array}$ & Remarks \\
\hline $\begin{array}{l}\text { Iberta....... } \\
\text { ocbester..... } \\
\text { elle......... }\end{array}$ & $\begin{array}{l}\text { Nov. } 8 \\
\text { Nov. } 8 \\
\text { Nov. } 8\end{array}$ & & & $\begin{array}{l}\text { Fruit buds dried up. Leaf buds started by December. } \\
\text { Fruit buds dried up. Leaf buds started by December. } \\
\text { Fruit buds dried up. Leaf buds started by December. }\end{array}$ \\
\hline $\begin{array}{l}\text { lberta....... } \\
\text { ochester..... } \\
\text { elle........ }\end{array}$ & $\begin{array}{l}\text { Dec. } 1 \\
\text { Dec. } 1 \\
\text { Dec. } 1\end{array}$ & & & $\begin{array}{l}\text { Fruit buds dried up. } \\
\text { Fruit buds dried up. } \\
\text { Fruit buds dried up. }\end{array}$ \\
\hline $\begin{array}{l}\text { lberta........ } \\
\text { ochester...... } \\
\text { elic......... }\end{array}$ & $\begin{array}{l}\text { Jan. } 3 \\
\text { Jan. } 3 \\
\text { Jan. } 3\end{array}$ & $\begin{array}{l}\text { Jan. } 20 \\
\text { Jan. } 20 \\
\text { Jan. } 20\end{array}$ & $\begin{array}{l}17 \\
17 \\
17\end{array}$ & $\begin{array}{l}\text { Center and apical buds opened first. } \\
\text { Only a few buds opened, rest dried up. } \\
\text { Only a few buds opened, re } t \text { dried up. }\end{array}$ \\
\hline $\begin{array}{l}\text { lberta....... } \\
\text { ochester..... } \\
\text { e'le......... }\end{array}$ & $\begin{array}{l}\text { Jan. } 19 \\
\text { Jan. } 19 \\
\text { Jan. } 19\end{array}$ & $\begin{array}{l}\text { Feb. } 2 \\
\text { Feb. } 8 \\
\text { Feb. } 8\end{array}$ & $\begin{array}{l}14 \\
20 \\
20\end{array}$ & $\begin{array}{l}\text { All buds opened. } \\
\text { All buds opened. } \\
\text { All buds opened. }\end{array}$ \\
\hline $\begin{array}{l}\text { Iberta....... } \\
\text { ochester ...... } \\
\text { elle......... }\end{array}$ & $\begin{array}{l}\text { Feb. } 9 \\
\text { Feb. } 9 \\
\text { Feb. } 9\end{array}$ & $\begin{array}{l}\text { Feb. } 23 \\
\text { Feb. } 23 \\
\text { Feb. } 23\end{array}$ & $\begin{array}{l}14 \\
14 \\
14\end{array}$ & $\begin{array}{l}\text { Winter killed buds on twigs; few opened. } \\
\text { Winter killed buds on twigs; few opened. } \\
\text { Winter killed buds on twigs; few opened. }\end{array}$ \\
\hline $\begin{array}{l}\text { lberta........ } \\
\text { ochester..... } \\
\text { elle......... }\end{array}$ & $\begin{array}{l}\text { Feb. } 20 \\
\text { Feb. } 20 \\
\text { Feb. } 20\end{array}$ & $\begin{array}{l}\text { Mar. } 2 \\
\text { Mar. } 2 \\
\text { Mar. } 2\end{array}$ & $\begin{array}{l}10 \\
10 \\
10\end{array}$ & $\begin{array}{l}\text { Center and apicąl buds first. } \\
\text { Center and apical buds first. } \\
\text { Center and apical buds first. }\end{array}$ \\
\hline $\begin{array}{l}\text { iberta ........ } \\
\text { tocbestcr...... } \\
\text { elle......... }\end{array}$ & $\begin{array}{l}\text { Mar. } 3 \\
\text { Mar. } 3 \\
\text { Mar. } 3\end{array}$ & $\begin{array}{l}\text { Mar. } 14 \\
\text { Mar. 14-15 } \\
\text { Mar. 14-15 }\end{array}$ & $\begin{array}{l}11 \\
12 \\
12\end{array}$ & $\begin{array}{l}\text { Center and apical buds first, } \\
\text { Center and apical buds first. } \\
\text { Center and apical buds first. }\end{array}$ \\
\hline $\begin{array}{l}\text { lberta........ } \\
\text { iochester...... } \\
\text { ielle......... }\end{array}$ & $\begin{array}{l}\text { Mar. } 13 \\
\text { Mar. } 13 \\
\text { Mar. } 13\end{array}$ & $\begin{array}{l}\text { Mar. } 20 \\
\text { Mar. 22 } \\
\text { Mar. 20-21 }\end{array}$ & $\begin{array}{l}7 \\
9 \\
8\end{array}$ & $\begin{array}{l}\text { Center and apical buds first. } \\
\text { Center and apical buds first. } \\
\text { Center and apical buds first. }\end{array}$ \\
\hline $\begin{array}{l}\text { Iberta....... } \\
\text { lochester..... } \\
\text { ielle......... }\end{array}$ & $\begin{array}{l}\text { Mar. } 25 \\
\text { Mar. } 25 \\
\text { Mar. } 25\end{array}$ & $\begin{array}{l}\text { Mar. } 29 \\
\text { Mar. } 29 \\
\text { Mar. } 29\end{array}$ & $\begin{array}{l}4 \\
4 \\
4\end{array}$ & \\
\hline
\end{tabular}

"well." He also observed that the same season "gave further evidence hat Elberta and other varieties of its group, such as Early Elberta ind J. H. Hale, start into growth upon the occurrence of the first warm days of winter and are later injured by cold. On the other land, varieties like Carman and Greensboro, which respond less quickly to periods of warm weather, escaped with slight loss." Strausbaugh (1921) found in studying three varieties of plums that he one which would withstand the lowest temperature also had the ongest and most profound rest period. Pojarkova (1924) found a imilar correlation with species of Ribes, but not with those of Acer and Berberis. Strausbaugh also noted that during the rest period the 
moisture content of the fruit buds of the semi-hardy plum varieties fluctuated with the temperature. In contrast the moisture content of a hardy variety, Assiniboine, remained fairly constant. Johnson (1923) found that moisture contents of buds of several varieties of peach were negatively correlated with bud hardiness.

Undoubtedly, the extent and the degree of rest influence hardiness by delaying the response of the buds to temperatures that usually bring about growth. As has been shown, warm spells are of frequent occurrence during the winter months in West. Virginia, particularly in the territory west of the Alleghenies. The peach, with its rest period soon over, responds to these favorable growing temperatures of midand late winter, and then, if the weather becomes very cold later, is injured. On the other hand, the apple, with a long, deep rest period, is not influenced so much by these temperatures. This is probably one of the causes for its remarkable bud hardiness during winter.

\section{POLLEN DEVELOPMENT}

Although outwardly no apparent growth takes place during the rest period, development within the fruit bud continues. Flower parts form and enlarge, and by the end of the rest period in January, most of them can be easily distinguished. The time that perceptible cell differentiation began in pollen and ovules following the rest period, and the extent of their development at successive dates during the dormant season, were taken as indices of the changes going on within the fruit bud. Considerable study was given to the differentiation and growth of the fruit buds during the winters of 1921-22 and 1922-23. Fruit buds were collected at intervals from trees of each of the three varieties, Elberta, Rochester, and Belle. Buds were selected separately as follows: (1) from short growths up to $3 \frac{1}{2}$ inches in length from the inside of the tree, and (2) from long outside terminal growths, 12 to 24 inches in length, or more. Buds prepared for study from the long branches were further classified into three lots--those from basal, median, and terminal positions on the branch. In the winter of 1922 , collections of buds were also made from laterals on the long growths. The material was killed immediately in one percent chromo-acetic acid, imbedded in paraffin, sectioned, and stained in either Haidenhain's or Fleming's Triple stain.

The stages in the development of pollen at the different dates of collection are shown in Tables 5 to 9 , inclusive: 


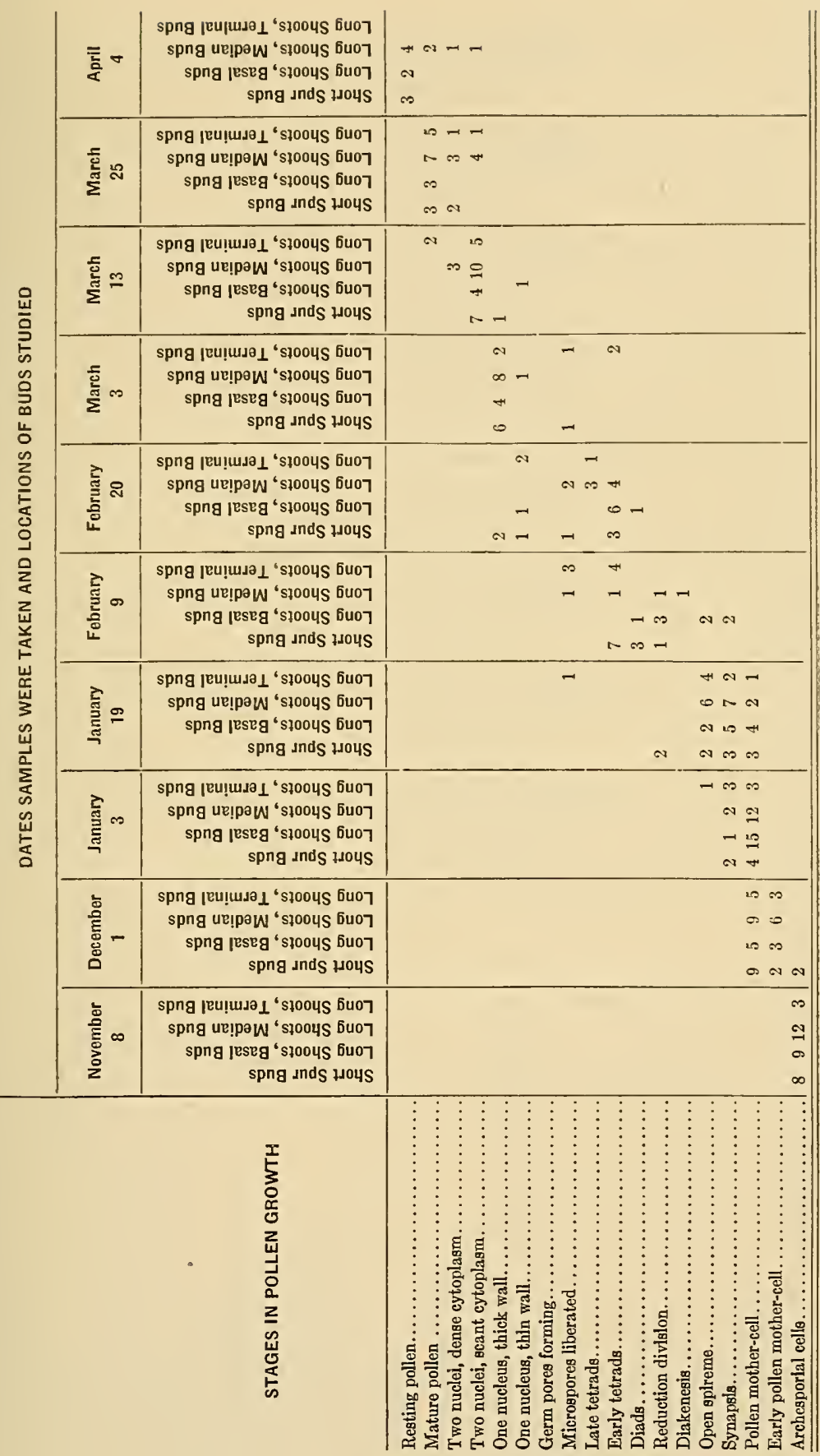




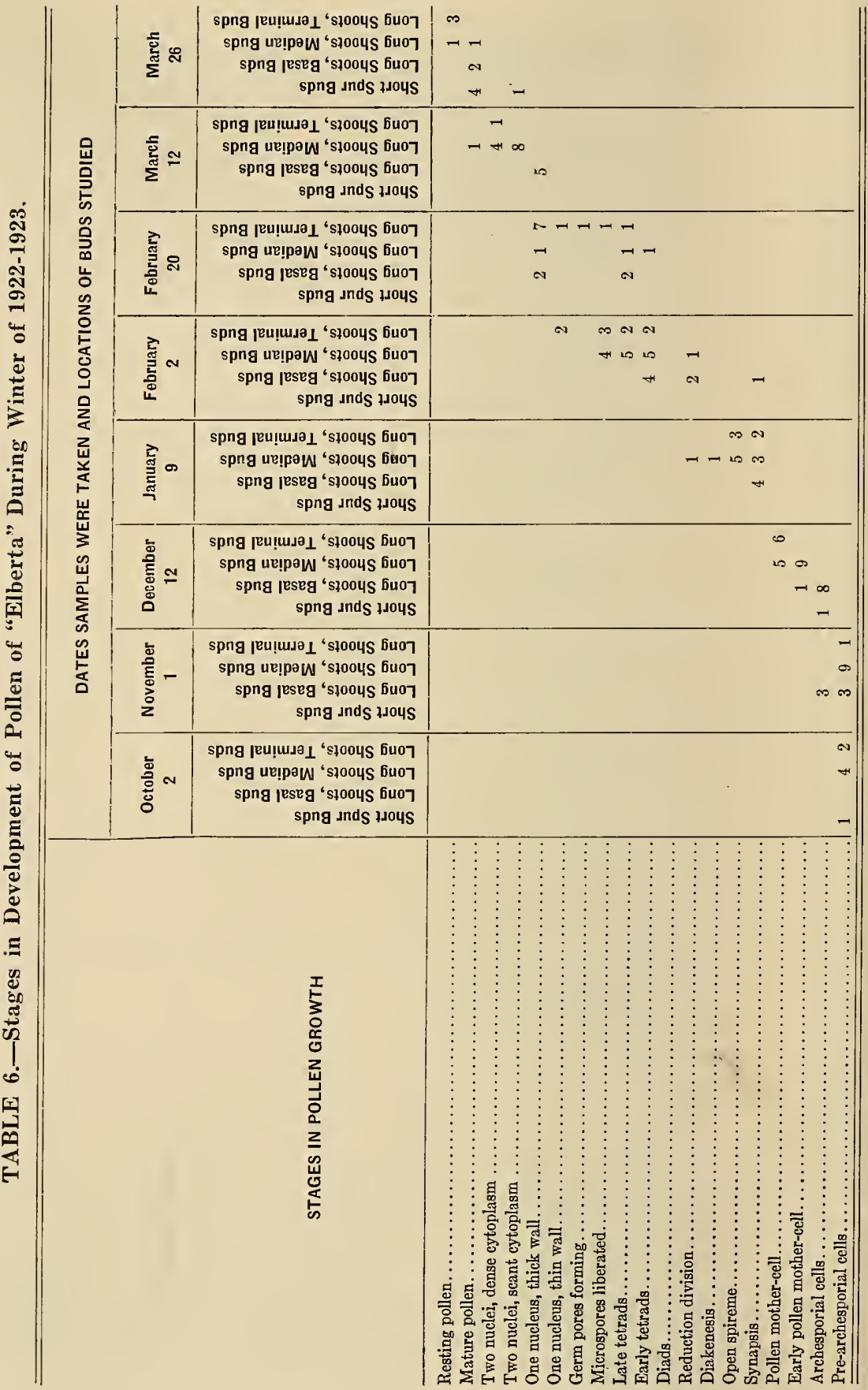




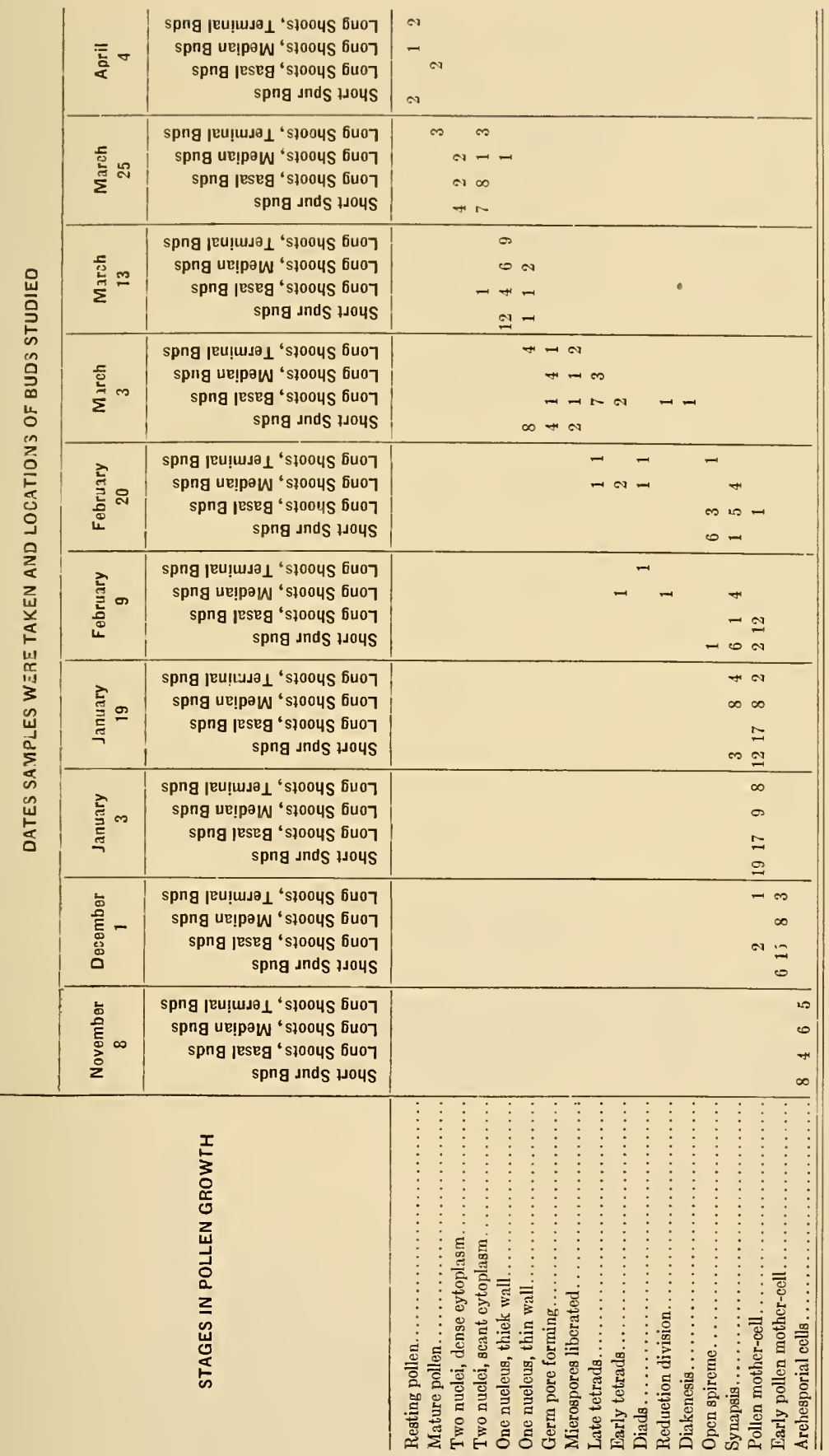




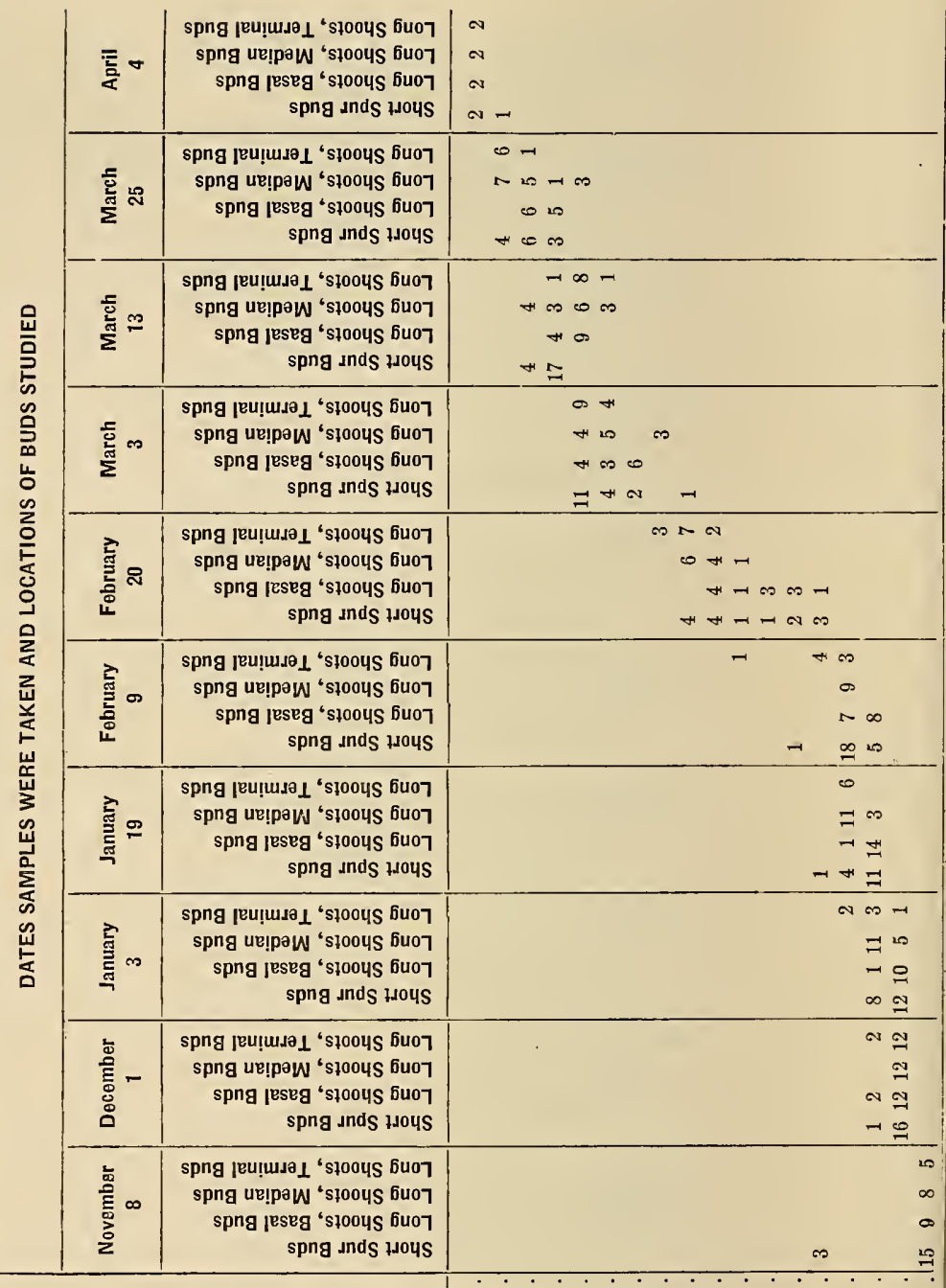

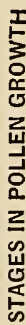

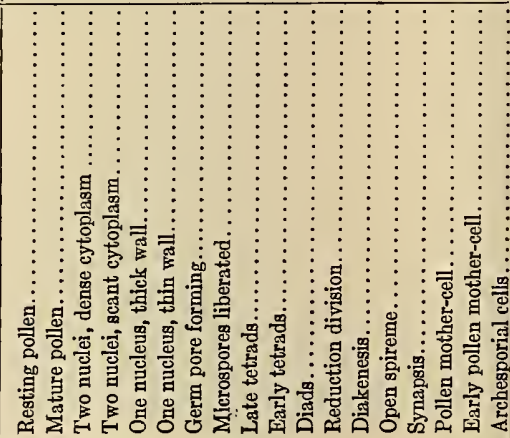




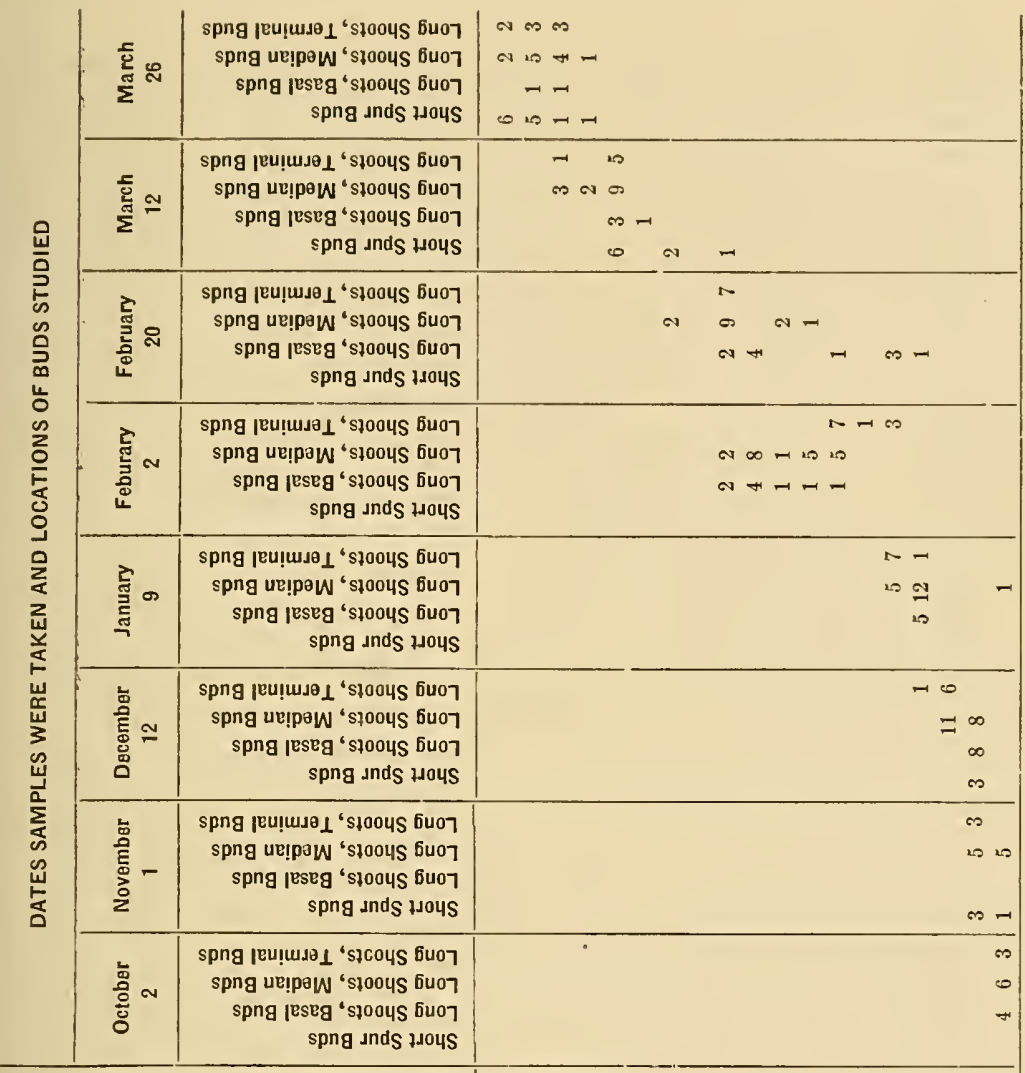

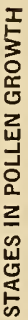


Since some buds showed quite a range in degree of developmen of pollen, the most advanced stage, which is the one recorded, wa determined for each flower bud. Development of pollen at th different dates was not so advanced as that observed by Drinkar (1909) in Virginia for the variety Luster. He found pollen mothes cells early in November, tetrad formation on December 19, and polle grains' on January 18. Farr (1920) also found a more advanced stag of pollen development, than that recorded in these studies, with number of varieties growing at different places in West Virgini: Maryland, Virginia, and New Jersey. When pollen growth durin the winter of 1921 is compared with growth during the winter of 192 there are, in general, no marked differences to be observed. If, hov ever, collections had been made on the same dates each year, perhar some differences would be shown.

All varieties show a great range in pollen development, especiall from February until April-(Tables 10 to 11). Thus on February 1922 (Table 10), two out of 30 buds of Elberta show pollen mother-cel in synapsis while four buds have liberated microspores. On Januar 9, 1923, one Elberta bud had not yet formed archesporial cells (Tab 11). Drinkard (1909) found some pollen mother-cells still in t] tetrad stage at the end of January, although in most buds polle grains had been formed. The studies of Farr (1920) also show co. siderable range in development at the different dates that collectios were made. At nearly every collection, Elberta buds showed a wid range in development than did buds of Belle and Rochester. Tb undoubtedly indicates a greater sensitivity to environmental factor or, in other words, a less profound rest period.

Both Table 10, for the winter of 1921, and Table 11, for $t$ ? winter of 1922, show Elberta buds to be further advanced by ear January than those of Belle or Rochester. Rochester buds seem develop somewhat more slowly than do buds of Belle. Farr (192 found that, during January, Elberta and Champion buds were $t$ most advanced, with Belle buds the farthest behind and Carman bu intermediate.

These studies also show the relation that exists between the sta of pollen development, and (a) the position of the bud upon the tw. and (b) the length of the twig (Tables 5 to 9 ). Differences in $c$ velopment in the pollen mother-cells became more pronounced duri synapsis, in the early part of January. At this time the pollen fri the majority of the terminal and median buds had forged ahead development. Basal buds apparently did not eatch up until $t$ 


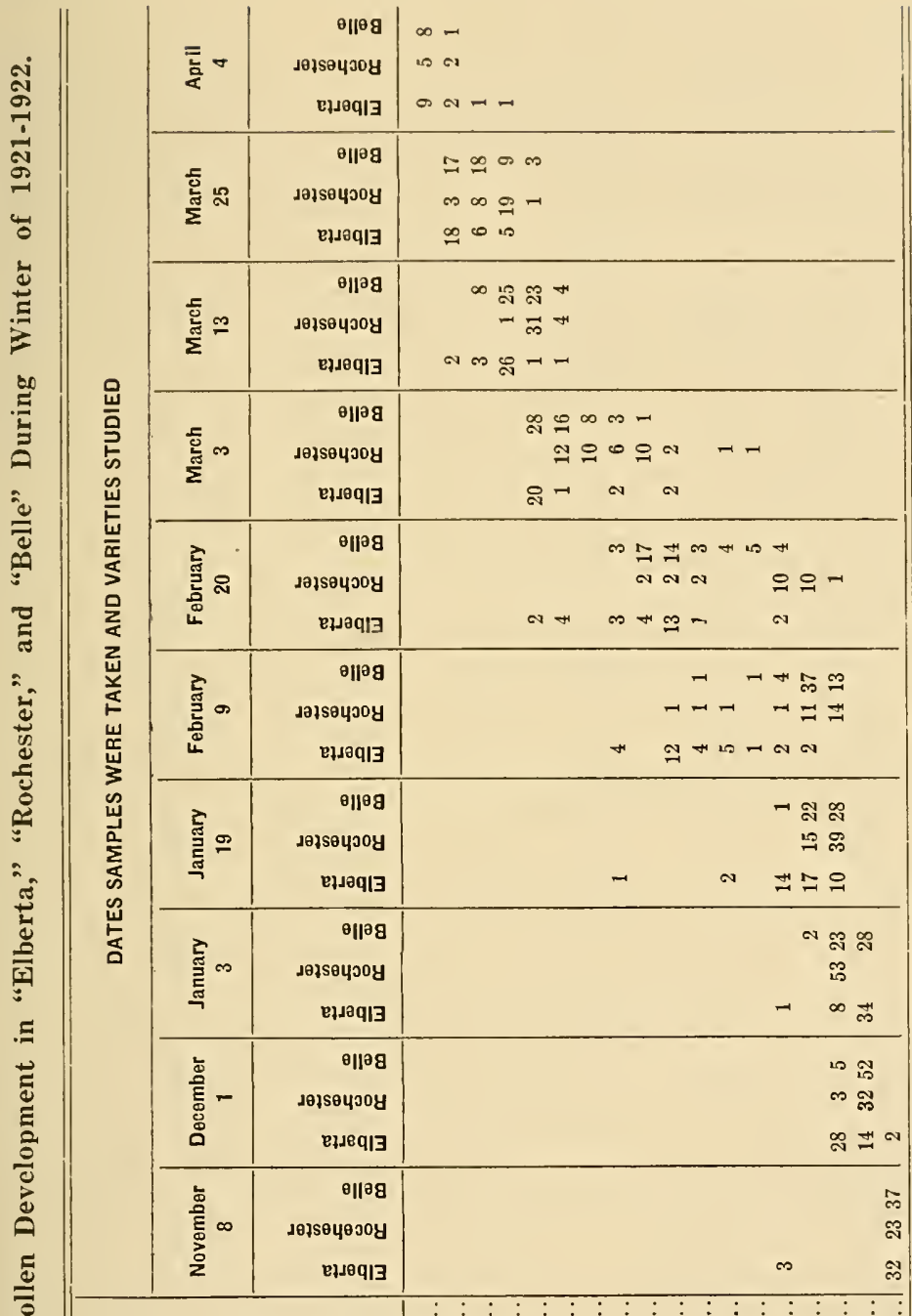




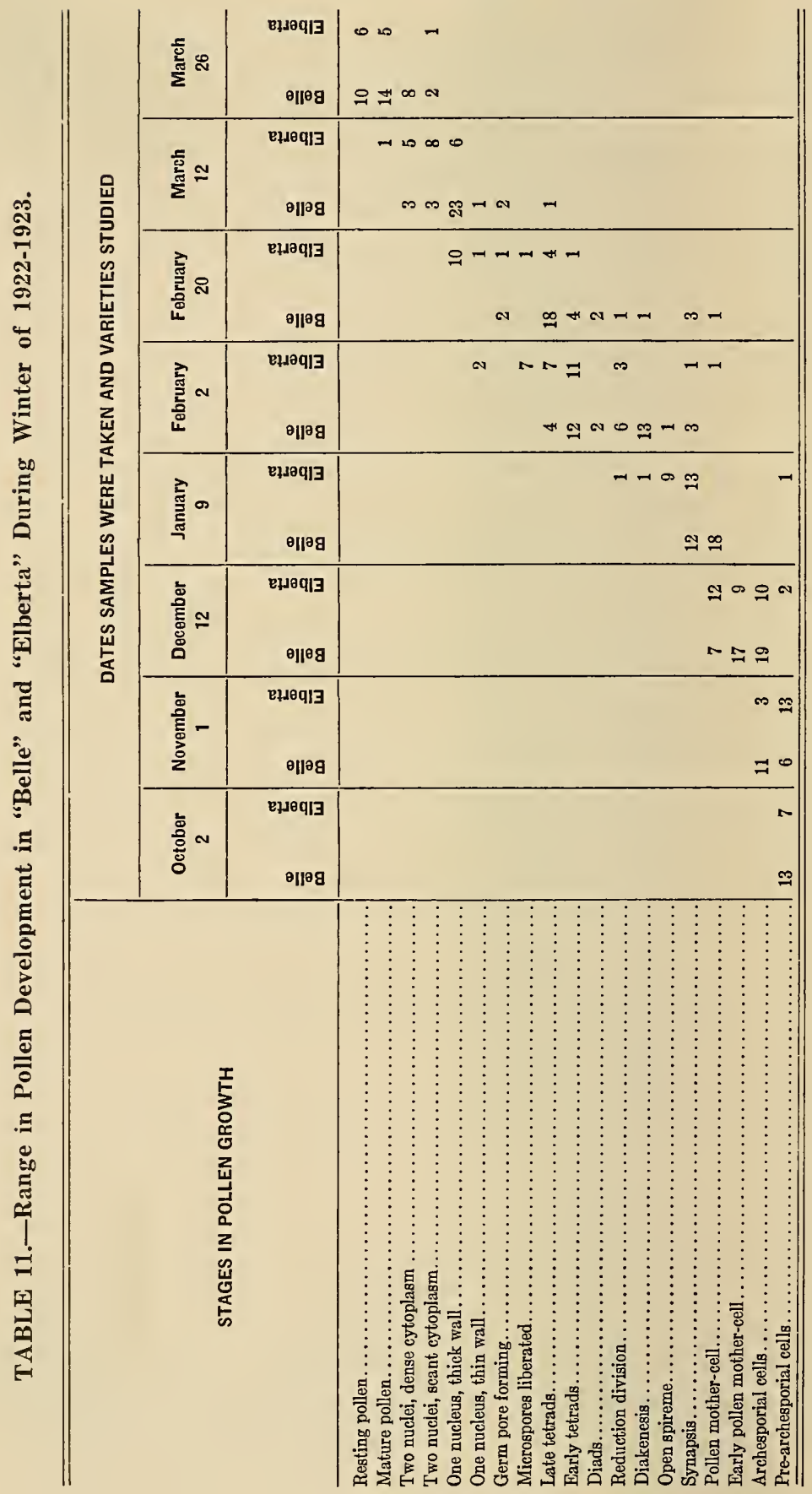


llen was near maturity. Pollen from most of the buds on the short iside "spurs" maintained a position intermediate between pollen from tsal and median buds on the longer growths. Placing the buds from different positions on the tree according to the average degree of Ilen derclopment during January and February, the following order found: (1) the terminal buds on outside shoots 12 inches or re in length, (2) the median buds from the same shoots, (3) buds f)m short inside "spurs" up to six inches in length, and (4) basal ds from the long outside shoots. Since fruit-bud initiation is known begin first on the basal portions of shoots, the rate of development median and terminal buds must be faster in order that they be ther advanced by January. Farr (1920) says, "There is no rela$n$, apparently, between the position of the bud on the twig and its ste of development." He noted, however, that double and triple ds are not as far advanced as single buds, and that they generally : found near the proximal end of the twig. Roberts (1922) found it a similar relationship between the degree of development and the mber of fruit buds borne at a single node held for the sour cherry. F; studies also showed (1917) the "least total development of the ssom buds on the shortest growths, the greatest amount on the dium-length growths, and moderate development on the longest "wths." On long terminal growths in the cherry, median buds re most developed, terminal buds least, and basal buds intermediate. Te buds most advanced were also the least hardy.

While pollen of basal buds seemed to be at the same stage of delopment at bloom as pollen of median and terminal buds, the buds mselves were not always at the same stage. In some seasons, parillarly early ones, terminal and median buds opened several days ore basal buds. This was very noticeable in the early spring of 7 (See Figure 2).

\section{RELATIVE DEVELOPIIENT OF POLLEN AND OVULE}

While attention was given primarily to pollen development as an rex of growth during the winter months, because of the fact that vole flower buds were sectioned it was possible to determine also in time to time the changes in the ovule. In the flower buds of Eerta which were collected on November 8, 1921, there was no wth on the carpel wall to indicate the first stages of ovule formai2. At this time pollen from the same flowers was in the archesporial stage. The first outgrowths from the carpel wall were found on uary third. By January 19 these occurred much more generally 
and were much larger in some ovaries, but, as yet, the start of ovul development had not been made in some pistils. This variation i: ovule growth is interesting in view of the stages reached in polle: development. Table 5 shows that pollen growth at this same dat (January 19) had advanced considerably since the earlier collection:

In the collections made on February 20, ovule development ha gone still farther, but as yet no growing points for the integument had appeared. It was not until March 3 that these were found at time when the pollen grains from the same flowers had been liberate from the tetrad wall (Table 5). By March 13, both integuments wer present in some ovules, but they were not closed sufficiently to for the funiculus. Growth was relatively rapid between March 13 and 2 At the latter date the integuments were nearly closed in some ir stances', and there was a pronounced growth in the ovule, generally Megaspore mother-cells were not found in the collections made 0 . April 4, just as the flowers were opening. At this time the polle grains were in a resting condition. The embryo sac, then, is no formed until after the first flowers open. It will be seen from th foregoing, therefore, that owing to the nature of the growth stage: pollen can be used as an index of winter growth to better advantag than the ovule because of the relatively later formation of the latte:

\section{INFLUENCE OF CULTURE AND FERTILIZATION ON FRUII BUD HARDINESS}

Relatively little attention has been given by investigators to th factors affecting the hardiness of the fruit bud, especially those the can be modified by the grower. The factors affecting wood hardines have been studied much more extensively. Chandler (1907) as result of his investigations believes that fruit-bud hardiness can $b$ increased by inducing late growth and a tardiness in both entering an coming out of the rest period. As a result, the buds do not respon so quickly to spells of warm weather in January and February. Lat growth can be brought about by pruning, fertilization, or cultivation He found that thinning the previous crop tended to increase th hardiness of the flower buds. Garcia and Rigney (1914) found greate bud killing in the irrigated alfalfa sod part of a peach orchard tha in the cultivated portion. On the other hand, Crane (1924) in peac fertilizer work in West Virginia found markedly greater killing ( fruit buds on nitrated trees than on those not receiving it. Lat applications of nitrate of soda killed a still higher percentage of fru buds. The total number of live buds, however, on the nitrated tre 


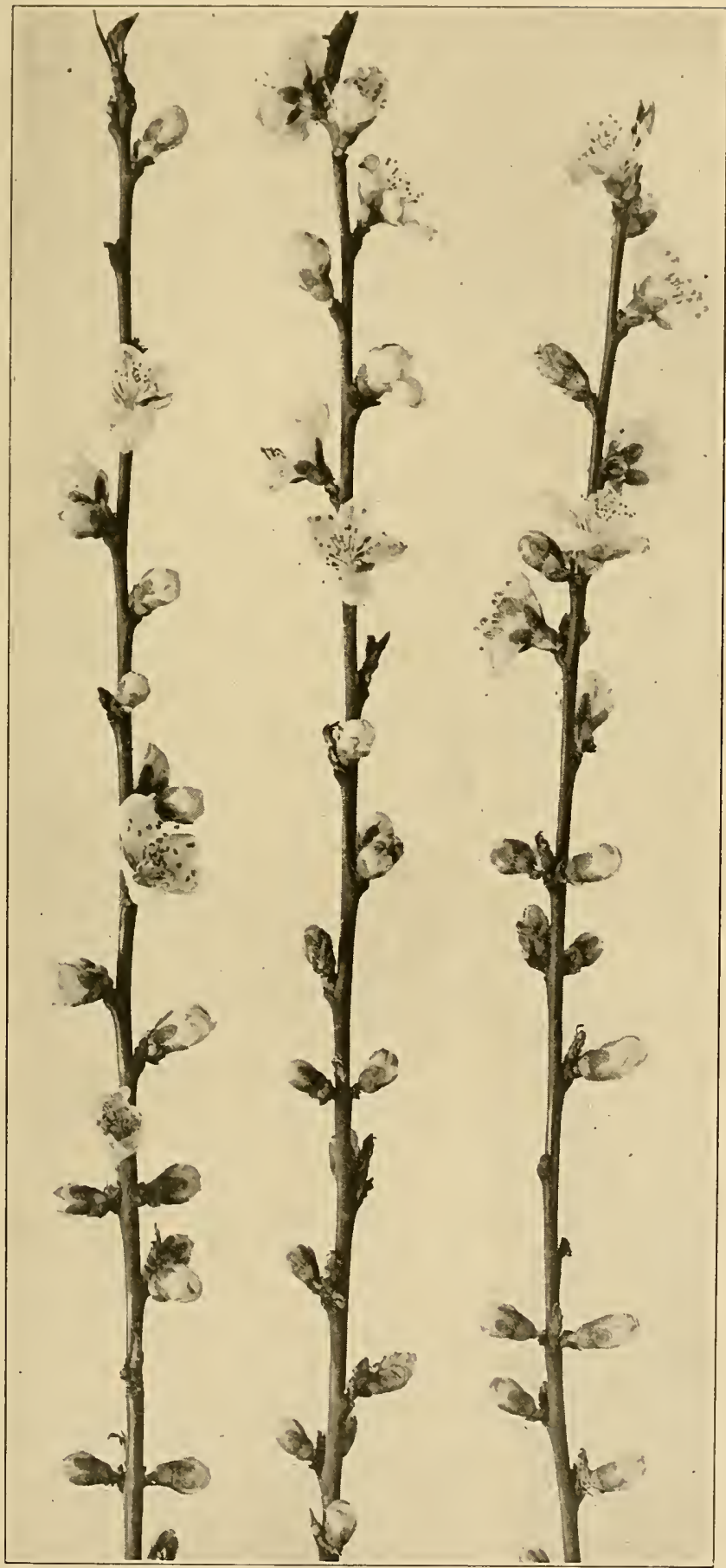

Fig. 2.-Terminal and median buds opening before basal ones. 
was greater than on the checks because more buds were produced per shoot.

In view of these somewhat contradictory results further investi gations were needed to determine the effect of culture on the exten of the rest period and also upon the internal differentiation and growtr of the fruit bud. Kirby (1918) found that on spurs' of the Jonathar and Grimes apples, fruit-bud initiation occurs first on trees in sod $\mathrm{He}$ also found that fruit buds from trees in sod continued to be in more advanced stage of development throughout the dormant seasor than did those from trees under cultivation.

It would s'eem, therefore, from the foregoing findings, that there is also a possibility of influencing the rate of fruit-bud development in the peach and thereby its hardiness by different cultural practices Accordingly, in the spring and summer of 1924, some tests were made in the Variety Orchard on the Experiment Station Farm at Morgan town to determine the effect of applying nitrate of soda, at different times during the growing season, upon the hardiness of the fruit buds the following winter. The trees were eight years old and in good condition, although making a short terminal growth at the time the experiment was started. The pruning and culture were uniform on all trees under test. Again, 200 nodes were used as the basis for com. parison, and were taken from one tree under each treatment. The winter of 1924-25 was so severe that fruit buds of only the hardiest varieties survived. It is during such conditions, however, that a treatment must be effective, if it is to have commercial value.

The data in Table 12, while not conclusive, are suggestive. The nitrated trees of Rochester and Salwey had noticeably fewer dead fruit buds than the checks. The earlier applications showed the same tendency in Belle, Bilmeyer, and Elberta, while with Champion there seemed to be no difference between the check and nitrated trees. During the winter of 1923-24, Carman and Waddell trees in sod had a noticeably greater percentage of their fruit buds killed than adjoining trees under cultivation. Comparison can be made between the fruit. bud killing in the varieties included in Table 3 with those of Table 12 . The earlier applications of nitrate of soda appeared to induce slightly greater hardiness in the fruit buds.

Other seasons with less killing might show greater differences between the treatments than a season like 1924-25, the severity of which was near the limits of temperature endurance for fruit buds of the peach. 
ABLE 12.-Effect of Fertilization with Nitrate of Soda on Fruit-Bud Killing (1924-1925) in the Variety Orchard at Morgantown.

\begin{tabular}{|c|c|c|c|c|}
\hline Varioties & $\begin{array}{c}\text { Times } \\
\text { of } \\
\text { Application }\end{array}$ & $\begin{array}{l}\text { Amounts } \\
\text { Applied } \\
\text { in Pounds }\end{array}$ & $\begin{array}{c}\text { Parcentages } \\
\text { of } \\
\text { Buds Alive }\end{array}$ & Remarks \\
\hline 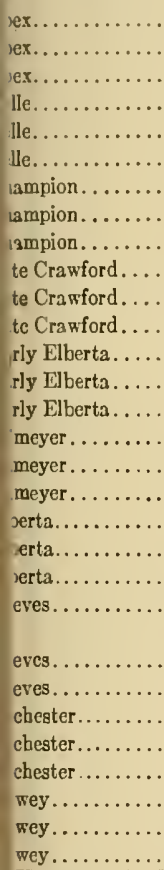 & $\begin{array}{l}\text { April } 23 \\
\text { July } 15 \\
\text { Check } \\
\text { April } 23 \\
\text { July 15 } \\
\text { Check } \\
\text { April } 23 \\
\text { July 15 } \\
\text { Check } \\
\text { April 23-July } 15 \\
\text { April } 23 \\
\text { Check } \\
\text { April } 23 \\
\text { Sept. 10 } \\
\text { Check } \\
\text { April } 23 \\
\text { July 15 } \\
\text { Check } \\
\text { April 23 } \\
\text { July 15 } \\
\text { Check } \\
\text { Apr. 23, July } 15 \\
\text { Sept. 10 } \\
\text { Sept. 10 } \\
\text { Check } \\
\text { April } 23 \\
\text { Sept. 10 } \\
\text { Check } \\
\text { Apr. 23,July } 15 \\
\text { Sept. 10 } \\
\text { Check }\end{array}$ & $\begin{array}{l}3 \\
4 \\
4 \\
4 \\
4 \\
4 \\
4 \\
4\end{array}$ & $\begin{array}{c}0 \\
\text { less than } 1 \\
\text { less than } 1 \\
2 \\
1 \\
2 \\
11 \\
7 \\
12 \\
0 \\
0 \\
0 \\
0 \\
0 \\
0 \\
2 \\
\text { less than } 1 \\
\text { less than } 1 \\
2 \\
\text { less than } 1 \\
\text { less than } 1 \\
\\
0 \\
0 \\
0 \\
22 \\
29 \\
6 \\
9 \\
4 \\
\text { less than } 1\end{array}$ & $\begin{array}{l}\text { Occasional live bud on short growths. } \\
\text { Occasional live bud on short growths. } \\
\text { Occasional live bud on short growths. } \\
\text { Occasional live bud on short growths. } \\
\text { Occasional live bud on short growths. } \\
\text { Occasional live bud on short growths. }\end{array}$ \\
\hline
\end{tabular}

\section{SUIMIMARY}

The winters of West Virginia are characterized by periods of oderately high temperatures which cause considerable bud growth the peach. When these high temperature periods are followed by dden cold spells, especially toward late winter, conditions occur hich favor bud killing.

The different peach varieties raried greatly in the hardiness of e fruit buds. Elberta and J. H. Hale were among the tenderest irieties, although not so much so as Reeves, the least hardy of all e varieties under observation. Greensboro was one of the hardiest irieties and with some of the others, like Carman and Mayflower, me through the winter of 1924-25 with some live buds. 
Fruit-bud killing was not so extensive in the eastern part of tl state as in the western part during the winters that this problem w: studied. A crop loss may occur either east or west of the mountair from the killing of the fruit buds during the winter.

There was considerable variation in the way in which the differer varieties may be affected by winter temperatures. The killing of th flower buds or the killing of the young pistils may eliminate a larg proportion of the buds as far as setting is concerned. The killing c pistils, as in Late Crawford, was more extensive in 1921-22 than durin any of the other years in which these varieties were studied.

Pollen development increased in rate early in December. Anthe changes afforded a more sensitive index to growth than blooming test although the latter showed the approximate time of the break in th rest period.

These studies covering two seasons showed that the rest perio ends earlier in Elberta than in Belle or Rochester. This conditio favors a greater growth response in Elberta during the warme periods of January and February than in Belle and Rochester. Ther was much variation in the stages of pollen development found at given date and likewise a given stage was found for some time later.

There was considerable variation in the degree of development $c$ the fruit buds on different parts of the tree by mid-winter, as measure by degree of pollen differentiation. Generally speaking, buds on th bases of the terminal twigs were latest in development, buds on th middle of the twigs next, and the terminal buds farthest advances The fruit buds borne on the short spurs or branches on the interio of the tree were on the average slightly ahead of the basal buds 0 the outside terminals. The indications are that the buds farthes advanced were the least hardy, although there is seemingly som evidence against this in Table 2 .

Ovule development was noticeable at a much later date than tha of pollen. The first stages of ovule formation were indicated $b$. growing points on the carpel wall on January 3. Differentiation 0 integuments was noticed on March 3. Megaspore mother cells wer not found in collections made on April 4, just as flowers were openine The embryo sac, then, is not formed until after the first flowers oper

Nitrate applications were made in an attempt to influence bu hardiness. The results indicated a slight increase in hardiness on tree making but a short terminal growth. 


\section{LITERATURE CITED}

AKE, M. A. and FARLEY, A. J.

1911. Report of the horticulturist. N. J. Agr. Exp. Sta. An. Rpt. $32: 63-86$.

$1 \mathrm{KE}, \mathrm{M} . \mathrm{A}$.

1916. REPORT OF THE Department of Horticulture. N. J. Agr. Exp. Sta. Rpt. 37:71-72.

ike, M. A., and Connors, C. H.

1918. REPORT OF the department of horticulture. N. J. Agr. Exp.

Sta. Rpt. $39: 41-64$.

ANDLER, W. H.

1907. THE WINTER KILLING OF PEACH BUDS AS INFLUENCED BY PREVIOUS treatment. Mo. Agr. Exp. Sta. Bul. 74.

ANDLER, W. H.

1908. HARDINESS OF PEACH BLOSSOMS AND YOUNG FRUIT AS INFLUENCED By THE CARE OF THE ORCHARD. Mo. Agr. Exp. Sta. Circ. of Information 31 .

NE, H. L.

1924. EXPERIMENTS In FERTILIZING PEACH trees. W. Va. Agr. Exp. Sta. Bul. 183.

NKARD, A. W.

1909-10. Fruit-Bud formation and Development. Ann. Rpt. Va. Agr.

Exp. Sta. 159-205.

2R, C. H.

1920. DORMANCY AND WINTER-KILLING OF PEACH BUDS. Trans. Iowa Hort. Soc. $55: 99-116$.

ZCIA, F. and RIGNEY, J. W.

1914. hardiness of Fruit budS AND Flowers to Frost. New Mexico Agr. Exp. Sta. Bul. 89.

GSON, F. R.

1924. OBSERVATIONS ON THE REST PERIOD OF DECIDUOUS FRUIT TREES IN A mild Climate. Proc. Am. Soc. Hort. Sci. 151-155.

NARD, R. L.

1910. AN EXPERIMENTAL STUdY OF THE REST PERIOD in Plants. Mo. Agr. Exp. Sta. Bul. 1. iNSON, E. S.

1923. MOISTURE RELATIONS OF PEACH BUDS DURING WINTER AND SPRING. Md. Agr. Exp. Sta. Bul. 255.

BY, R. S.

1918. A STUDY OF THE FORMATION AND DEVELOPMENT OF THE FLOWER BLDS OF JONATHAN AND GRIMES GOLDEN IN RELATION TO DIFFERENT TYPES OF Soll management. Proc. Iowa Acad. Sci. 25:265-287. :LL, I. H.

1924. HARDINESS OF PEACH VARIETIES. Trans. Ind. Hort. Soc. 167-168. ARKOVA, ANTONIA.

1924. WINTERRUKE, RESERVESTOFFE, UND KALTERESISTENZ BEI HOLZpFlanzen. Ber. Deutsch. Bot. Ges. 42:10:420-429. 
ROBERTS, R. H.

1917. WINTER INJURY to CHERRY BLOSSOM BUDS. Proc. Am. Soc. H Sci. 105.

ROBERTS, R. H.

1922. THE DEVELOPMENT AND WINTER INJURY OF CHERRY BLOSSOM BL Wis. Agr. Exp. Sta. Res. Bul. 52.

Strausbaugh, P. D.

1921. DORMANCY AND haRdiNESS IN THE PLUM. Bot. Gaz. 71:337-357. THAYER, P.

1916. Winter Killing of Peach Buds. Ohio Agr. Exp. Sta. Mo. F $1: 311-312$. 


HECKMAN

BINDERY INC.

\section{JUNE 99}




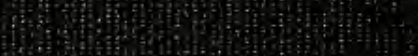

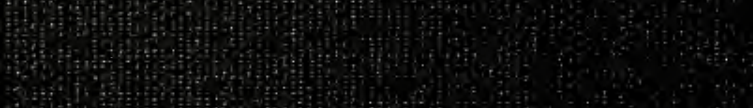

(4)

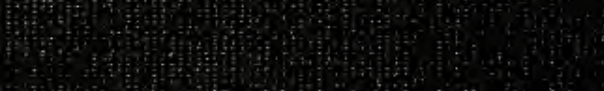

Hitio

10.

(19)

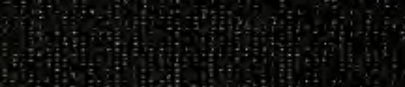

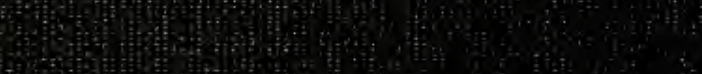

(19) (6) (7) H. He 